\title{
Effect of Hydrothermal Vent Bacterial İsolates in Farming Fenneropenaeus Indicus for Water Quality, Growth and Survival
}

\section{Varatharajan $\mathrm{GR}^{1,2 *}$, Vasudevan $\mathrm{L}^{1}$, Bhat $\mathbf{M}^{1}$, Ray $\mathrm{D}^{1}$, Rajasabapathy $\mathrm{R}^{1}$ and Ravindran $\mathrm{C}^{1 *}$}

${ }^{1}$ CSIR-National Institute of Oceanography, India

${ }^{2}$ Key Laboratory of Marine Bioresource and Eco-Environmental Science, College of Life Sciences and Oceanography and Key Laboratory of Optoelectronic Devices and Systems of Ministry of Education and Guangdong Province, College of Optoelectronic Engineering Shenzhen University, China

*Corresponding author: Varatharajan GR \& Ravindran C, Biological Oceanography, CSIR-National Institute of Oceanography (CSIR) Dona Paula, Goa - 403 004, India, tel: Ph No.0832-2450442; Email: sarauvraj@gmail.com; cravindran@nio.org

\section{Abstract}

Bioremediation of aquaculture water is increasing rapidly in the sustainable development of aquaculture industries. In this study, Bacillus megaterium (VBW147) and Bacillus subtilis subsp. spizizenii (VSD609) were assessed for their potential in water remediation using prawn culture tanks. During the experimental period of eight days, physicochemical parameters were analyzed with and without feed conditions treated with above bacterial strains. After treatment, $B$. megaterium reduced $1.091 \mathrm{mgL}-1$ of ammonia, $0.011 \mathrm{mgL}-1$ of nitrite, $0.153 \mathrm{mgL}-1$ of nitrate and $0.292 \mathrm{mgL} 1$ of phosphates with feed conditions, while $0.811 \mathrm{mgL}-1$ of ammonia, $0.577 \mathrm{mgL}-1$ of nitrite, $0.127 \mathrm{mgL}-1$ of nitrate, $0.111 \mathrm{mgL}-1$ of phosphates were removed in starve conditions. B. subtilis did not show any reduction, with ammonia but eliminated $0.041 \mathrm{mgL}-1$ of nitrite, $0.258 \mathrm{mgL}-1$ of nitrate and $0.239 \mathrm{mgL}-1$ of phosphate with feed conditions. B. Subtilis although removed $0.453 \mathrm{mgL}-1$ of ammonia and $0.521 \mathrm{mgL}-1$ of nitrite, it was also found inefficient in the removal of nitrate and phosphate in starving conditions. Thus, $B$. Megaterium was found more efficient in removing the toxic substances than that of the $B$. subtilis and both strains did not show any pathogenic effect on juvenile prawns.

Keywords: Nutrients; Bacillus; Probiont; Water Purification; Bioremediation

\section{Introduction}

Aquaculture has developed into a major food production sector. It is a fast-growing food production area in many developed and developing countries. Therefore, maintaining production levels in a controlled environment has become a major area of concern in aquaculture practices. In particular, various physicochemical parameters in this controlled environment play a vital role in maintaining water quality and productivity [1-3]. Water quality for aquaculturists refers to the physicochemical nature of water that enables successful propagation, including proper survival and growth of the desired organisms. Accumulation of aquaculture wastes like residual food and faecal matters leads to deterioration of water quality and causes disease outbreaks $[4,5]$. The abundance of various nitrogen species in this water body mainly determines the quality of water. Nitrogen is added to the pond in the form of fertilizer and formulated feed. Excess nitrogen in pond assimilation controls the deterioration of water quality by increasing the concentration of nitrogenous compounds. A large amount of nitrogen-containing compounds quickly accumulate into dissolved ammonia and nitrite, which is harmful to fish, shrimp and shrimp even at low concentrations [3]. Nitrite is usually present at low concentrations in natural systems, except when there is an imbalance because it is a common intermediate in nitrification and denitrification, catabolic ammonification and nitrate assimilation [6]. Ammonia is 
excreted as the final product of protein catabolism and may be toxic if allowed to accumulate. Due to ammonia toxicity, hyperactivity, convulsions, loss of balance, lethargy and coma are some of the common symptoms in aquaculture animals. Aquaculture ponds are most likely to show a reduction in sub lethal death or suppression of immunity in fish growth, resulting in a significant increase in the acute toxicity of death [7]. Moreover, it is also toxic to living organisms as it causes eutrophication in water bodies [8]. Even though, dietary phosphorous is an essential component of fish feeds as it improves weight gain and feeds conversion ratio. Excretion of ingested phosphorus as faecal matters results in poor water quality due to increased algal growth and eutrophication [9].

Indiscriminate use of antibiotics and chemotherapeutants for improving the health of fishes and rearing the quality of watercan also lead to the growth of drugresistant pathogenic microorganisms. These drawbacks paved the way for searching an alternative, the probiotics, which is most widely accepted as an environment-friendly aquaculture treatment [10]. Thus, the use of probiotics to resist the pathogens is being suggested as a better remedy than administering antibiotics, and moreover, it is now gaining acceptance for pathogen control in aquaculture and as an agent for water purification by involving in the nitrogen cycle [11].

In the aquaculture field, the usage of probiotics is widely accepted with an increasing demand for environmentfriendly aquaculture. Therefore, researchers are paying more attention to probiotics in the aquaculture fields. Generally, Bacillus spp. used as a probionts, it's improve the water quality and reduce the toxic substances in the aquaculture fields. Porubcan [12] reported on two attempts at bacterial treatments to improve water quality and production yield of Penaeus monodon. Floating bio-filters pre-inoculated with nitrifying bacteria decreased the amounts of ammonia and nitrite in the rearing water and increased shrimp survival [12]. The introduction of Bacillus spp. in proximity to pond aerators reduced chemical oxygen demand, and increased shrimp harvest. In several studies used Bacillus spp as a probionts and its increased survival, production and water quality [12-17]. As a probiotics, the usage of terrestrial bacteria in aquaculture has a limited success and characteristics of bacteria depend upon the environment in which they live. Thus, identification of potential probiotics from marine environment where they grow optimally is a better approach. Therefore, in this study we used the marine Bacillus spp bacteria which was isolated from the hydrothermal vent used as a probionts. The present study was aimed at assessing the hydrothermal vent bacterial isolates would-be reduce the toxic substances (ammonia, nitrite, nitrate and phosphorus) and enrich the water quality in aquaculture farming of Fenneropenaeus indicus culture tanks.

\section{Materials and Methods}

\section{Collection and Maintenance of Animal}

The prawns (Fenneropenaeus indicus) were collected from the government shrimp farm, Old Goa, India. Throughout the experiment, the temperature and salinity of water in the culture tank was maintained at $28-30^{\circ} \mathrm{C}$ and $28.0 \mathrm{ppt}$ respectively. During this investigation, the prawns were fed with flakes (Higashimaru Co. Ltd feeds).

\section{Bacterial Strains used as Probiotics}

In this study, two bacterial strains of Bacillus species (B. megaterium and $B$. subtilis) were used as probiotics. These gram-positive strains VBW147 (Bacillus megaterium) and VSD609 (Bacillus subtilis subsp. spizizenii) were isolated from shallow active Espalamaca hydrothermal vent field near Azorean Island Faial in the North Atlantic Ocean [18].

The bacterial isolates were maintained on agar slants, subcultured periodically and stored at $4^{\circ} \mathrm{C}$. Prior to the experiment, organisms were revived at $37^{\circ} \mathrm{C}$ for 24 hours on nutrient agar (Himedia) prepared in 50\% seawater or Zobell marine agar (HiMedia).

\section{$16 S$ rRNA Gene aAnalyses and GenBank Accession Number}

The DNA was extracted from the bacterial strains using the Lane [19] method. The 16S rRNA gene fragments were amplified through PCR by using the primers, 27F ( $5^{\prime}$-AGA GTT TGA TCC TGG CTC AG-3') and 1492R (5'-GGT TAC CTT GTT ACG ACT T-3') were used with the required cycle numbers at $94^{\circ} \mathrm{C}$ for $60 \mathrm{sec}, 53^{\circ} \mathrm{C}$ for $60 \mathrm{sec}, 72^{\circ} \mathrm{C}$ for $90 \mathrm{sec}$ and a final extension of $7 \mathrm{~min}$ at $72^{\circ} \mathrm{C}$. The $16 \mathrm{~S}$ rRNA genes of bacterial strains VBW147 and VSD609 were determined by using a 3130xl automated DNA sequencer (Applied Biosystems, Foster City, CA, USA). The gene sequences were compared with relative gene sequences available at the Genbank database (http://www.ncbi.nlm.nih.gov/ blast/) and the GenBank accession numbers were obtained for those strains, KC534338 and KC534274, respectively.

\section{Tank Setup and Experimental Design}

Initially, juvenile prawns (Fenneropenaeus indicus) were acclimatized under controlled 150 conditions of water temperature, salinity and $\mathrm{pH}$ for 24 hours and fed with flakes (HIGASHIMARU Co. Ltd feeds). The tank length and breadth were 22 and $19 \mathrm{~cm}$ respectively, and each tank was fed with $10 \mathrm{mgL}^{-1}$ of feed. The feed particle size was 0.08 to 0.13 in diameter(mm). Prawns were separated 
into groups and introduced into the tanks (30 numbers of juvenile prawns/tank), each tank was filled with water (1.5 to $2 \mathrm{~L}$ ) having uniform salinity of $28 \pm 2.0 \mathrm{ppt}$. A schematic diagram of the tank setup and experimental design is illustrated in figure 1 .

Tank 1 was with feed and without probiotic, which served as a positive control (Ctrl WF -control with feed) and triplicate was also made (Tank 7 and 8) and Tank 2 was without feed and probiotic, which served as a negative control (Ctrl WOF - control without feed) and triplicate was also made (Tank 9 and 10 ). In tank 3 and $4,1 \times 10^{5}$ cells $\mathrm{L}^{-1}$ of $B$. megaterium were inoculated with $10 \mathrm{mgL}-1$ of feed (MWF - B. megaterium with feed) and without a feed (MWOF - B. megaterium without feed), respectively and triplicate was also made (Tank 11, 12, 13 and 14). Similarly, in tank 5 and 6, $1 \times 10^{5}$ cells L $^{-1}$ of $B$. subtilis were inoculated with $10 \mathrm{mgL}^{1}$ of feed (SWF B. subtilis with feed) and without a feed (SWOF - B. subtilis without feed), respectively and triplicate was also made (Tank 15, 16, 17 and 18). All these tanks were maintained in triplicates. The bacterial strains were added by the static immersion method. The entire experimental setup was carried out for up to 8 days without water exchange. Prawns were acclimatized in the tank with the above conditions for 1 to 4 days, and thereafter, water samples from each tank were analyzed for various physiochemical parameters on a daily basis for the next five days.

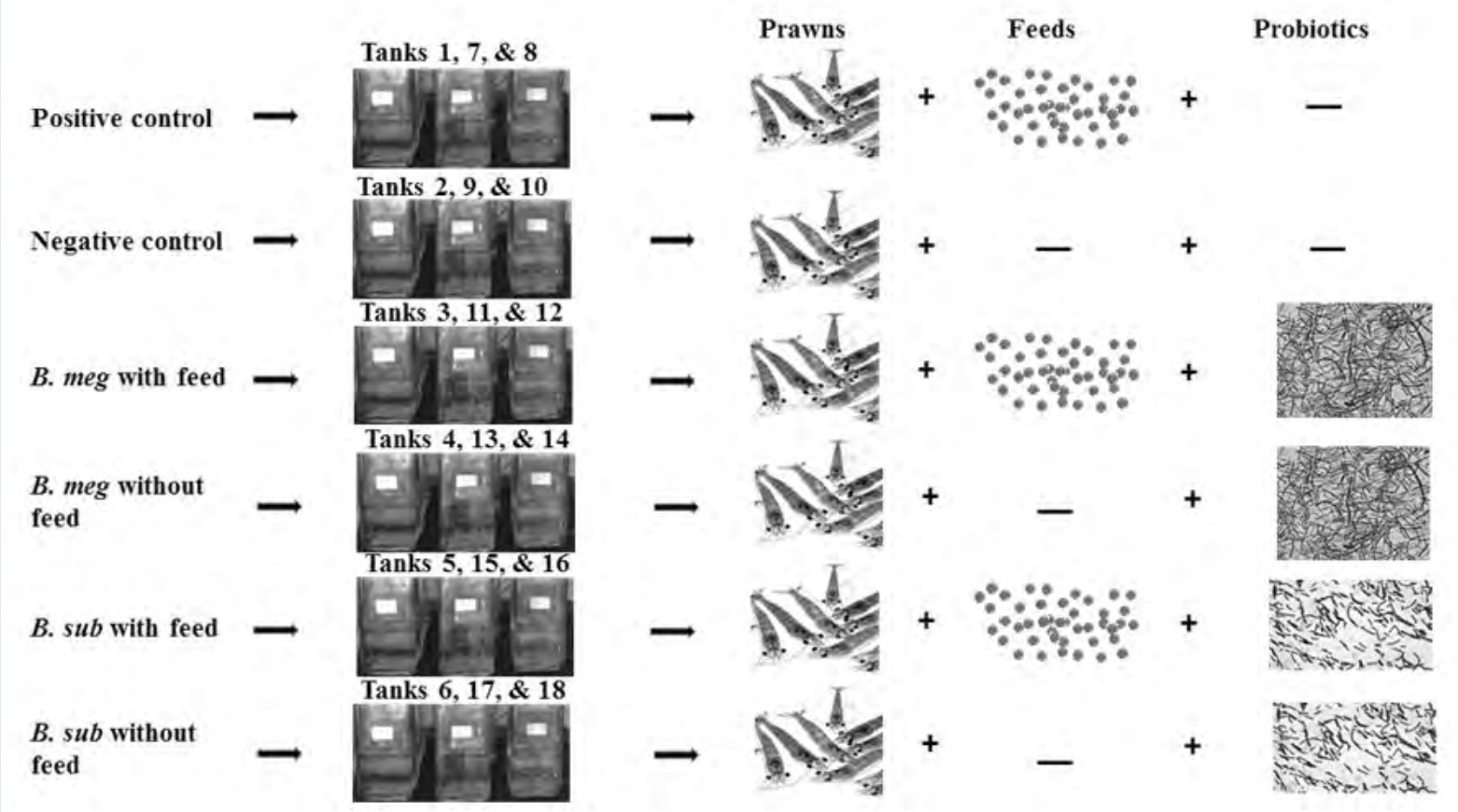

Figure 1: Schematic diagram of Tank setup and Experimental design.

\section{Analysis of Water Quality Parameters}

Water samples from each tank were analyzed for temperature, salinity, $\mathrm{pH}$, dissolved oxygen (DO), ammonia and various other nutrients on a daily basis. The salinity and temperature of the water samples were measured using a handheld refractometer (RHS-10ATC, Sinokit, Hong Kong) and multi-probe meter (Eutech), respectively. Throughout the experiment, water temperature and salinity were maintained within the limit of $27 \pm 1{ }^{\circ} \mathrm{C}$ and $28 \pm 2 \mathrm{ppt}$, respectively. $\mathrm{pH}$ of same water was monitored regularly using a Eutech multiprobe meter (CyberScan 600 Eutech Instruments, India). $\mathrm{pH}$ of water in all tanks was maintained at $7.6 \pm 0.2$. These above-controlled conditions were conceived and followed as per the reports documented from several prawns and fish aquaculture ponds. Dissolved oxygen in water samples was determined using the Winkler's titrimetric method. For dissolved ammonia and nutrients (e.g. Nitrite, Nitrate and Phosphate), water samples were collected, filtered and then analyzed by standard photometric methods using an Autoanalyzer (SKALAR, SAN++ Analyzer, The Netherlands).

\section{Statistical Analysis}

Statistical analysis was performed using the InfoStat software ver. 2012; $p \leq 0.05$ was regarded as statistically 
significant. The mean and median of replicate values were calculated from the obtained experimental data. The difference between control and test groups were evaluated using the Student t-test. All experiments were at least in triplicate and results are presented as average \pm standard error (SE) values.

\section{Results}

\section{Bacillus spp., from Hydrothermal Vent Region}

Two Bacillus species were used as probiotics. One is B. megaterium and another one is B.subtilis. These gram positive strains VBW147 (Bacillus megaterium) and VSD609 (Bacillus subtilis subsp. spizizenii) were isolated from shallow active Espalamaca hydrothermal vent field near Azorean
Island Faial in the North Atlantic Ocean. Bacillus species, B. megaterium and B.subtilis were selected based on the earlier reports on the effective enhancement of water quality by these species. Both the selected species showed their effectiveness in maintaining water quality and minimizing the effect of a toxic chemical in the prawn culture tank. Kumar, et al. [20] also suggested that $B$. subtilis can be used effectively as a commercial product for use in aquaculture. When some strains of Bacillus species were introduced in the ponds, an increase in the prawn survival rate was noted [21]. Additionally, Bacillus species have shown to possess adhesion abilities, produce bacteriocins (antimicrobial peptides) and provide immunostimulation [22], which is essential for aquaculture animals to survive in poor water quality conditions.
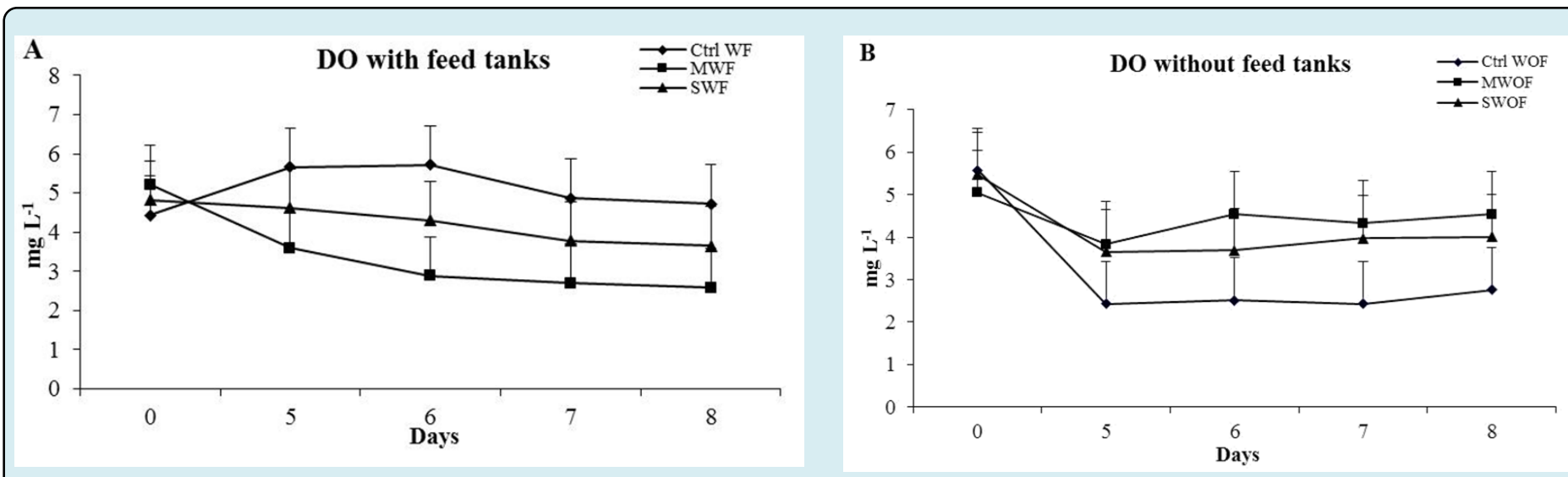

Figure 2: Comparative variations of dissolve oxygen (DO) in control and probiotic treated waters in laboratory prawn culture tanks; (A) Control tank with feed (Ctrl WF); tank water treated with B. megaterium and with feed (MWF); tank water treated with B. subtilis and with feed (SWF). (B) Control tank without feed (Ctrl WOF); tank water treated with B. megaterium and without feed (MWOF); tank water treated with B. subtilis and without feed (SWOF).

\section{Alteration of Dissolved Oxygen}

DO concentration values in the present study were 4.4 - 5.7 (Ctrl WF), 4.4 - 5.2 (MWF), 3.6-4.8 (SWF), 2.4-5.5 (Ctrl WOF), 3.8-5.0 (MWOF), and 3.6-5.4 (SWOF) $\mathrm{mg} \mathrm{L}^{-1}$. In the tanks containing probiotic MWF, DO was reduced to 2.072, $2.836,2.172$, and $2.143 \mathrm{mg} \mathrm{L}^{-1}(36 \%, 49 \%, 45 \%$, and $46 \%)$ on the $5^{\text {th }}, 6^{\text {th }}, 7^{\text {th }}$, and $8^{\text {th }}$ day, respectively. In comparison to the control tanks, the DO depletion rate in probiotic SWF tanks were $1.036,1.418,1.086$, and $1.071 \mathrm{mg} \mathrm{L}^{-1}(18 \%, 25 \%, 29 \%$, and $23 \%$ ) on the $5^{\text {th }}, 6^{\text {th }}, 7^{\text {th }}$, and $8^{\text {th }}$ day, respectively (Figure 2A). Results of DO levels in tanks without feed were found increased when compared to control tanks (Figure 2B)

\section{Alteration of Dissolved Ammonia}

In MWF tanks, ammonia was reduced to $0.351,0.783$,
0.376 , and $1.091 \mathrm{mg} \mathrm{L}^{-1}(29 \%, 27 \%, 14 \%$, and $46 \%)$ on the $5^{\text {th }}, 6^{\text {th }}, 7^{\text {th }}$, and $8^{\text {th }}$ day, respectively. Whereas in SWF tanks, ammonia level was increased in comparison to the control tanks from 0 day to $8^{\text {th }}$ day (Figure $3 \mathrm{~A}$ ). MWOF tanks had a reduction in ammonia concentration by $0.265,0.497,0.811$, and $1.539 \mathrm{mg} \mathrm{L}^{-1}(17 \%, 21 \%, 24 \%$ and $42 \%)$ on $5^{\text {th }}, 6^{\text {th }}, 7^{\text {th }}$ and $8^{\text {th }}$ day, respectively, when compared to the control tanks. But, in the tanks of SWOF, no reduction took place till the $7^{\text {th }}$ day, but on the $8^{\text {th }}$ day ammonia started to reduce by 0.453 $\mathrm{mg} \mathrm{L}^{-1}(12 \%)$ (Figure 3B). This can lead to an assumption that the natural nitrifying bacteria could have oxidized the ammonia and it is converted to nitrite then to nitrate. The values of ammonia concentration in the present study was $0.44-2.93$ (Ctrl WF), $0.37-2.36$ (MWF), $0.59-3.64$ (SWF), $0.16-3.69$ (Ctrl WOF), $0.18-2.59$ (MWOF) and $0.34-3.40$ (SWOF) $\mathrm{mg} \mathrm{L}^{-1}$. 

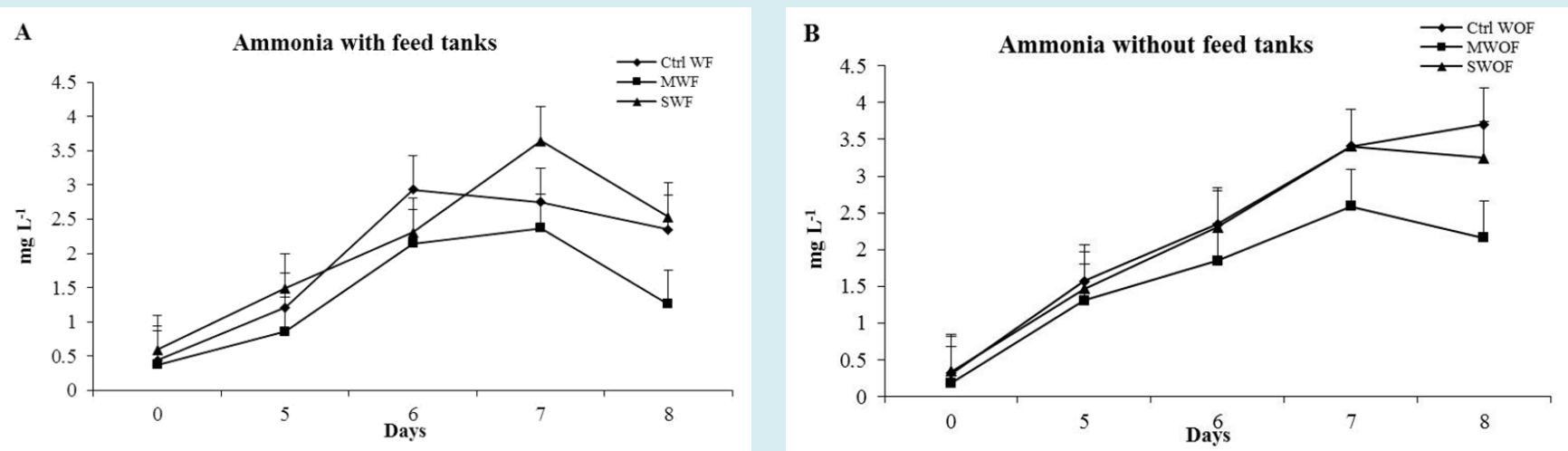

Figure 3: Comparative variations of dissolve ammonia in control and probiotic treated waters in laboratory prawn culture tanks; (A) Control tank with feed (Ctrl WF); tank water treated with B. megaterium and with feed (MWF); tank water treated with B. subtilis and with feed (SWF). (B) Control tank without feed (Ctrl WOF); tank water treated with B. megaterium and without feed (MWOF); tank water treated with B. subtilis and without feed (SWOF).

\section{Variation of Nutrient Load with Time}

Nitrite: Nitrite concentration was reduced from 0 day to $8^{\text {th }}$ day gradually in all tanks of MWF and SWF, when compared to the control tanks. In MWF tanks, nitrite reduction of 0.008 , $0.033,0.014$, and $0.010 \mathrm{mg} \mathrm{L}^{-1}(10 \%, 49 \%, 27 \%$ and $23 \%)$ was found on the $5^{\text {th }}, 6^{\text {th }}, 7^{\text {th }}$, and $8^{\text {th }}$ day, respectively. On the other hand, $0.047,0.004,0.006$, and $0.040 \mathrm{mg} \mathrm{L}^{-1}(61 \%, 10 \%$, $13 \%$ and $46 \%$ ) of nitrite was reduced in SWF tanks on the $5^{\text {th }}$, $6^{\text {th }}, 7^{\text {th }}$, and $8^{\text {th }}$ day, respectively (Figure $4 A$ ). In MWOF tanks, nitrite was reduced by $0.174,0.183,0.281$, and $0.577 \mathrm{mg} \mathrm{L}^{-1}$ $(92 \%, 91 \%, 87 \%$ and $95 \%)$ on the $5^{\text {th }}, 6^{\text {th }}, 7^{\text {th }}$, and $8^{\text {th }}$ day, respectively. Whereas in SWOF tanks, nitrite was reduced by $0.163,0.157,0.269$, and $0.521 \mathrm{mg} \mathrm{L}^{-1}(86 \%, 79 \%, 83 \%$ and $86 \%$ ) on the $5^{\text {th }}, 6^{\text {th }}, 7^{\text {th }}$, and $8^{\text {th }}$ day, respectively (Figure $4 \mathrm{~B}$ ). In the present study, nitrite concentration values were 0.01 - 0.08 (Ctrl WF), 0.01 -0.07 (MWF), 0.006-0.04 (SWF), 0.12 - 0.60 (Ctrl WOF), $0.002-0.04$ (MWOF) and $0.007-0.08$ (SWOF) $\mathrm{mg} \mathrm{L}^{-1}$.
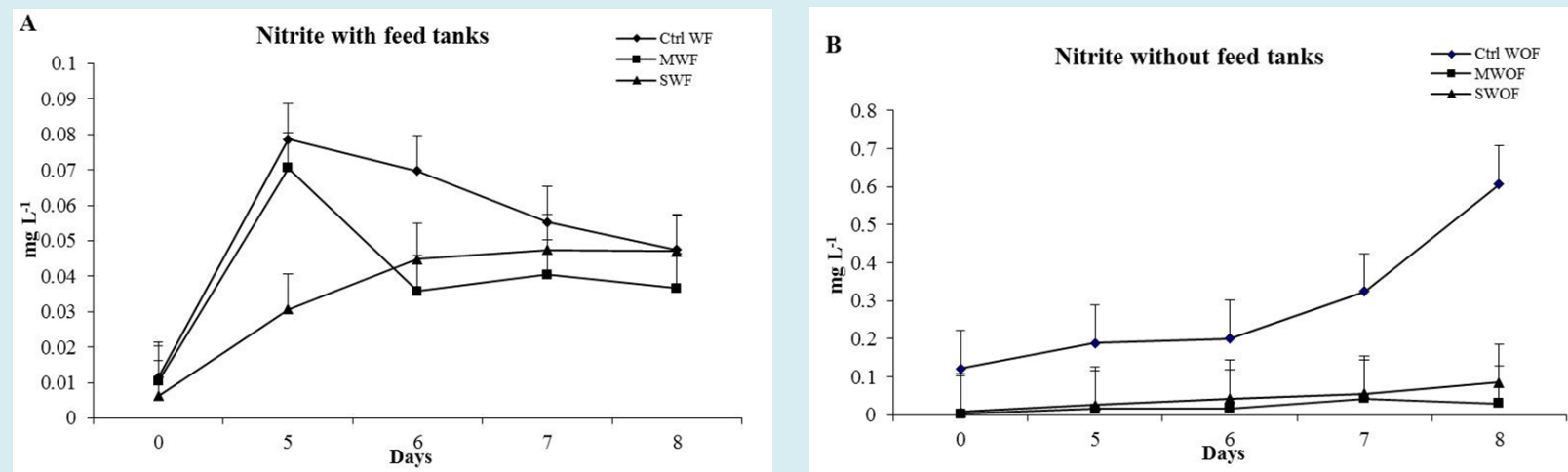

Figure 4: Comparative variations of nitrite in control and probiotic treated waters in laboratory prawn culture tanks-(A) Control tank with feed (Ctrl WF); tank water treated with B. megaterium and with feed (MWF); tank water treated with $B$. subtilis and with feed (SWF). (B) Control tank without feed (Ctrl WOF); tank water treated with B. megaterium and without feed (MWOF); tank water treated with B. subtilis and without feed (SWOF).

Nitrate: Nitrate concentrations of this study were noted as $1.06-1.79$ (Ctrl WF), $0.91-1.17$ (MWF), $0.97-1.23$ (SWF), $0.65-1.53$ (Ctrl WOF), $0.84-1.14$ (MWOF) and $0.97-1.34$ (SWOF) $\mathrm{mgL}^{-1}$. In MWF tanks, the nitrate was reduced by $0.851,0.318,0.220$, and $0.153 \mathrm{mg} \mathrm{L}^{-1}(47 \%, 21 \%, 16 \%$, and $14 \%)$ on the $5^{\text {th }}, 6^{\text {th }}, 7^{\text {th }}$, and $8^{\text {th }}$ day, respectively. Whereas in SWF tanks, nitrate was reduced by $0.726,0.416,0.083$, and
$0.258 \mathrm{mg} \mathrm{L}^{-1}(41 \%, 28 \%, 8 \%$, and $19 \%)$ on the $5^{\text {th }}, 6^{\text {th }}, 7^{\text {th }}$, and $8^{\text {th }}$ day, respectively (Figure $5 \mathrm{~A}$ ). On the $6^{\text {th }}$ and $7^{\text {th }}$ day, the nitrate reduction rate was very less compared to previous days in tanks containing probiotics, which may be due to the loss of denitrification. In MWOF tanks, nitrate was reduced by $0.222,0.323,0.359$, and $0.127 \mathrm{mg} \mathrm{L}^{-1}(17 \%, 27 \%, 23 \%$, and $13 \%$ ) on the $5^{\text {th }}, 6^{\text {th }}, 7^{\text {th }}$, and $8^{\text {th }}$ day, respectively. Whereas 
in SWOF tanks, nitrate was reduced by $0.080,0.223,0.202$, and $0.0 \mathrm{mg} \mathrm{L}^{-1}(6 \%, 17 \%, 17 \%$, and $0 \%)$ on the $5^{\text {th }}, 6^{\text {th }}, 7^{\text {th }}$, and $8^{\text {th }}$ day, respectively (Figure $5 \mathrm{~B}$ ). The B. megaterium in MWOF could have directly used the available nitrate in the water as its own nitrogen, thus the nitrate levels possibly change with respect to the microbial growth.
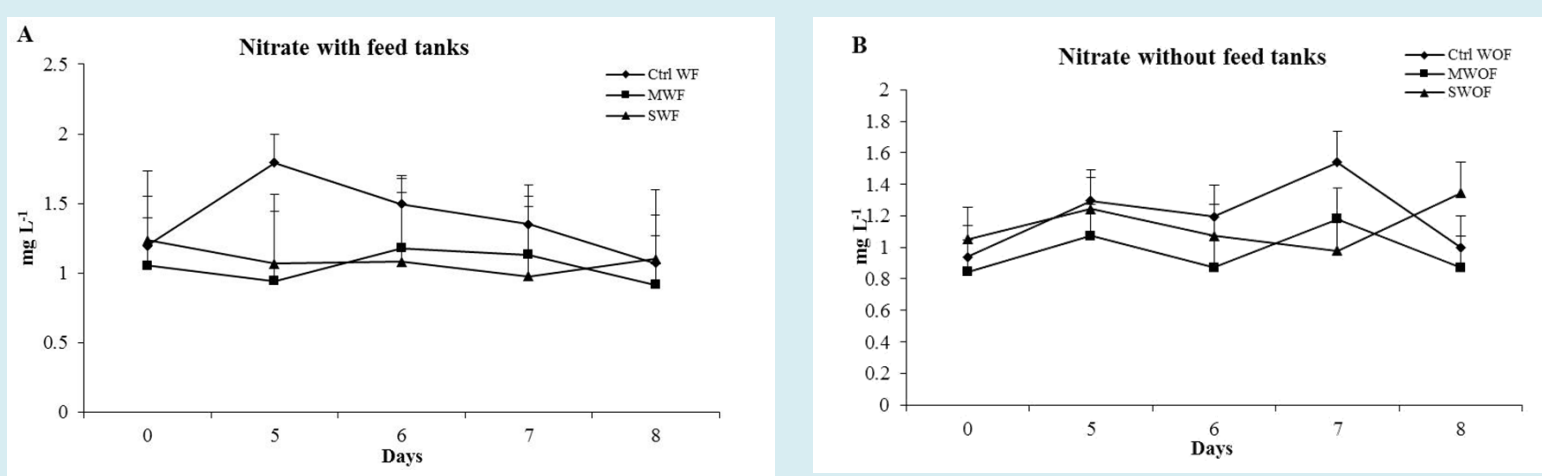

Figure 5: Comparative variations of nitrate in control and probiotic treated waters in laboratory prawn culture tanks. (A) Control tank with feed (Ctrl WF); tank water treated with B. megaterium and with feed (MWF); tank water treated with $B$. subtilis and with feed (SWF). (B) Control tank without feed (Ctrl WOF); tank water treated with B. megaterium and without feed (MWOF); tank water treated with B. subtilis and without feed (SWOF).

\section{Phosphate}

Phosphate level was reduced in both MWF and SWF tanks, when compared to control tanks on the final day of the experiment. In MWF tanks, the level of phosphate was reduced by $0.104,0.239,0.288$, and $0.292 \mathrm{mg} \mathrm{L}^{-1}(19 \%, 18 \%$, $25 \%$, and $30 \%$ ) on the $5^{\text {th }}, 6^{\text {th }}, 7^{\text {th }}$, and $8^{\text {th }}$ day, respectively. Whereas in SWF tanks, it was very less compared to MWF, the amount being less than $0.239 \mathrm{mg} \mathrm{L}^{-1}(18 \%)$ from $5^{\text {th }}$ to $8^{\text {th }}$ day (Figure 6A). It could be that the probiotics utilized phosphate for their metabolic activities thereby diminishing this nutrient in the pond water as reported by Rao [23]. In MWOF tanks, the phosphate level was reduced by 0.055 , $0.073,0.065$, and $0.111 \mathrm{mg} \mathrm{L}^{-1}(8 \%, 9 \%, 12 \%$, and $19 \%)$ on the $5^{\text {th }}, 6^{\text {th }}, 7^{\text {th }}$, and $8^{\text {th }}$ day, respectively. No reduction was observed in the SWOF tanks (Figure 6B). It may be due to the probiotics' inability to utilize phosphate as an energy source in without feed or starving condition. The results of phosphate concentration of the present study were noted as $0.37-1.33$ (Ctrl WF), 0.44-1.10 (MWF), 0.61-1.10 (SWF), $0.55-0.81$ (Ctrl WOF), $0.45-0.74$ (MWOF), and 0.58-1.10 (SWOF) $\mathrm{mg} \mathrm{L}^{-1}$. Wang, et al. [24] investigated the effect of commercial probiotics on water quality in shrimp P.vannamei ponds and showed significant reduction in the concentrations of phosphorus in pond water, compared to the control tanks from 0.1105 to $0.0364 \mathrm{mg} \mathrm{L}^{-1}$. Taoka, et al. [25] reported phosphate reduction from $13.0 \pm 3.9$ to 10.2 $\pm 3.0 \mathrm{mg} \mathrm{L}^{-1}$ in the Japanese flounder fish culture tank with commercial probiotics.
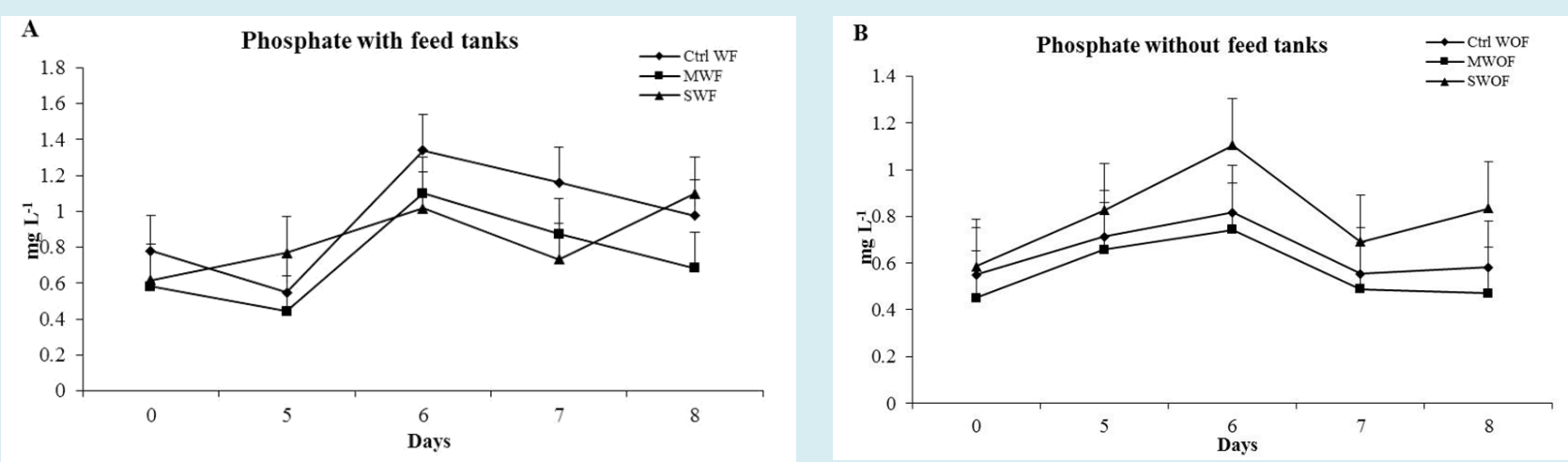

Figure 6: Comparative variations of phosphate in control and probiotic treated waters in laboratory prawn culture tanks. (A) Control tank with feed (Ctrl WF); tank water treated with B. megaterium and with feed (MWF);tank water treated with $B$. subtilis and with feed (SWF). (B) Control tank without feed (Ctrl WOF); tank water treated with B. megaterium and without feed (MWOF); tank water treated with B. subtilis and without feed (SWOF). 


\section{Discussions}

Bacillus species, B. megaterium and B. subtilis were selected based on the earlier reports on effective enhancement of water quality by these species. Both the selected species showed their effectiveness in maintaining water quality and minimizing the effect of toxic chemical in the prawn culture tank. Kumar, et al. [20] also suggested that B. subtilis can be used effectively as a commercial product for use in aquaculture. When some strains of Bacillus species were introduced in the ponds, an increase in the prawn survival rate was noted [21]. Additionally, Bacillus species have shown to possess adhesion abilities, produce bacteriocins (antimicrobial peptides) and provide immunostimulation [22], which is essential for aquaculture animals to survive in poor water quality conditions. The DO reduction could be due to the microbial decomposition of organic resources (feeds) depleting oxygen in the culture tanks. Results of DO levels in tanks without feed were found increased when compared to control tanks. In this condition, it may be due to the lack of depletion in the culture tanks as there were no organic resources (feeds), leading to an increase in the DO level. As per Verstraete and Focht [26], Bacillus is one of the species which can utilize the available nutrients in water and enhance the level of oxygen. Furthermore, various commercial probiotics containing Bacillus species were used in black tiger shrimp (Penaeusmonodon) culture ponds [27] and in the Nile tilapia (Oreochromis niloticus) [28] culture tanks for balancing the concentration which was in congruent with our study. Zhou, et al. [29] found ammonia concentration in the range of $0.0190-0.0323 \mathrm{mg}$ $\mathrm{L}^{-1}$ in larvae shrimp (Penaeus vannamei) culture tanks when using B. coagulans SC8168 strain as probiotics. Xie, et al. [30] used B. amyloliquefaciens as a probiotic supplement and reported initial ammonia concentration as 20 and 40 $\mathrm{mg} \mathrm{L}^{-1}$ with maximum removal rates of $59.8 \%$ and $79.8 \%$ at 48 hours in aquaculture water, respectively. El-Haroun, et al. [28] supplemented Nile tilapia Oreochromis niloticus (L.) culture with a commercial probiotic mixture containing B.licheniformis and B. subtilis for 17 weeks and reported ammonia concentration as $0.36-0.42 \mathrm{mgL}^{-1}$. In another study, Taoka, et al. [25] analyzed ammonia concentration in the Japanese flounder fish tank supplemented with commercial probiotics (mixed culture of bacteria and yeast) and found significant lowering of ammonia concentration in probiotics diet groups from $0.24 \pm 0.22$ to $0.12 \pm 0.10 \mathrm{mg} \mathrm{L}^{-1}$. In the current study, ammonia concentration was significantly higher in B. subtilis and lower in B. megaterium. If the ammonia concentration increases, the population of nitrifying bacteria will respond by rapidly increasing its abundance. Nitrification rates are sensitive to ammonia concentration, and they are regulated by environmental factors such as temperature, dissolved oxygen concentration, and $\mathrm{pH}$. The probiotic $B$. subtilis could have less or no necessity to utilize ammonia as their source of nitrogen. Thus, the process of ammonia oxidation was more in B. megaterium and less in B. subtilis. Nitrite results might suggest that the probiotics are able to use nitrite as an organic source of nitrogen under feeding condition. This Bacillus spp., belongs to nitrifying bacteria that can produce nitrite, nitrate and often utilize the organic sources of nitrogen rather than ammonia or nitrite. In starve condition, the probiotic $B$. megaterium could have more nitrification abilit when compared to $B$. subtilis, because it removed almost $95 \%$ of nitrite at the end of the experiment. Previously, few studies have reported strong nitrite removal ability in strains of B.subtilis [31] and B. lichenformis [32]. Xie, et al. [30] used Bacillus amyloliquefaciens as a probiotic supplement and showed $100 \%$ reduction after 48 hours in the aquaculture water. Zhou, et al. [29] used B. coagulans SC8168 strain as a probiotic supplement and reported nitrite concentration as $0.0067-0.0110 \mathrm{mg} \mathrm{L}^{-1}$ in larvae shrimp (Penaeus vannamei) culture tank. Thus, our study closely resembles with the results of above discussed studies on probiotic Bacillus species for their effective removal of nitrite. Nitrate results also infer that strain $B$. megaterium might have better denitrification role in comparison to that of $B$. subtilis. The present results were congruent with some earlier reports on probiotic Bacillus species, where nitrate reduction have improved the water quality. Lalloo, et al. [14] showed the inhibition activity of three out of nine Bacillus isolates against the pathogen and also its ability in lowering the concentrations of nitrate up to $76 \%$. Wang, et al. [24] used commercial probiotics in white shrimp Penaeus vannamei ponds and showed significant reduction of dissolved inorganic nitrogen concentration in treated ponds $\left(1.79 \pm 0.64 \mathrm{mg} \mathrm{L}^{-1}\right)$ compared to the control $(3.74 \pm 2.02 \mathrm{mg}$ $\mathrm{L}^{-1}$ ) ponds. In another study, Rui [33] reported the existence of Bacillus licheniformis as the most important factor for removing N03-N in the deteriorated aquaculture ponds. The reduction of phosphate concentration in the ornamental fish culture tanks has also been demonstrated through addition of Bacillus species [14]. Phosphorus occurs mainly in the form of phosphate and this element is recognized as the most critical factor in the maintenance of pond fertility. Thus, by using probiotics in the culture tanks and/or ponds, cultivators can reduce the accumulation of phosphate and other toxic substances in the aquaculture practices. The accumulation of nitrite and ammonia are highly toxic to aquaculture community. The use of biological agents for removing toxic substances and improving water quality have been tried and tested in various scientific studies, among which Pseudomonas, Bacillus and Alkaligenes are the most prominent strains that can reduce nitrate. Bacillus species are proved to be effective in removing nitrogen and enhancing water quality [34]. B. subtilis and B. cereus are able to grow under aerobic, facultative aerobic and anaerobic conditions, allowing simultaneous nitrification and denitrification process. In addition, physiological studies on Bacillus 
spp., revealed that it can utilize nitrate and nitrite as an alternative electron acceptors and nitrogen sources [30]. As a matter of fact, this study showed the role of $B$. megaterium and $B$. subtilis in removal of ammonia, nitrite and nitrate. Further, the study also suggests that $B$. megaterium might be an alternative Bacillus spp.,for effective removal of toxic substances, ammonia and nitrite.

\section{Conclusion}

In conclusions, Bacillus strains isolated from hydrothermal vent have shown to enhance the water quality in aquaculture, effectively. Among the two strains used, $B$. megaterium was found to be more effective strain than that of B. subtilis with and without feed, after 8 days of treatment (Figure 7A-F). This study revealed that these hydrothermal bacterial isolates have the potential to minimize the effect of toxic substances which in turn produce a better yield without any infection and/or mortality of the cultured animals. Therefore, such bacterial isolates of hydrothermal origin may be used as a possible probiotic strain for managing water quality in any aquaculture systems. However, it is essential to understand the mechanism of action in order to define selection criteria for potential probiotics and their efficacies in water purification.
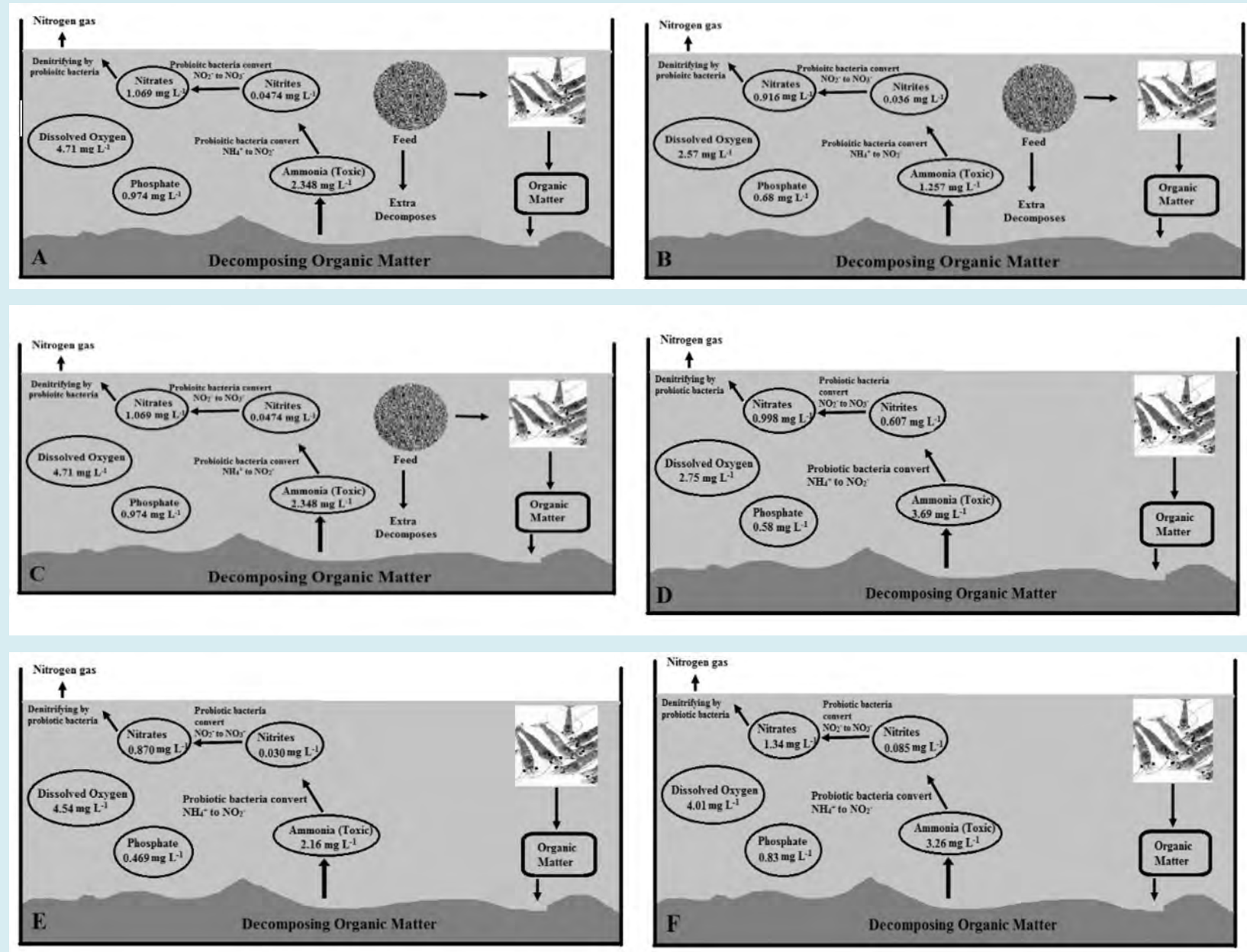

Figure 7: Schematic diagram of nitrification process (The biological oxidation of ammonia to nitrite followed by the oxidation of the nitrite to nitrate). Our experiment values of after 8 day treatment of probiotic's with and without feed tanks. (A) Control tank with feed. (B) B.megaterium probiotic treated tank with feed: has reduced 1.091, 0.011, 0.153, and 0.292 mgL1(46\%, $23 \%, 14 \%$ and $30 \%$ ) of ammonia, nitrite, nitrate and phosphate, respectively. (C) B.subtilis probiotic treated tank with feed: has reduced $0.0,0.041,0.258$, and $0.239 \mathrm{mgL}^{-1}(0 \%, 46 \%, 19 \%$ and $18 \%)$ of ammonia, nitrite, nitrate and phosphate, respectively. (D) Control tank without feed. (E) B. megaterium probiotic treated tank without feed: has reduced 0.811, 0.577,0.127, and $0.111 \mathrm{mgL}^{-1}$ (42\%, 95\%, 13\% and 19\%) of ammonia, nitrite, nitrate and phosphate, respectively. (F) B. subtilis probiotic treated tank without feed: has reduced $0.453,0.521,0.0$ and $0.0 \mathrm{mgL}^{-1}(12 \%, 86 \%, 0 \%$ and $0 \%)$ of ammonia, nitrite, nitrate and phosphate, respectively. 


\section{Acknowledgement}

The authors are thankful to the Director and Dr N. Ramaiah CSIR-National Institute of Oceanography for the laboratory facilities. CR acknowledge GRICES, Portugal and Department of Science and Technology, India for funding the trips to the DJCS site for sampling. Thanks to Dr Ana Colaco, IMAR - Department of Oceanography and Fisheries, University of Azores, Cais de Sta Cruz 9901-862, Horta, Portugal and Dr C. Mohandass, CSIR-National Institute of Oceanography, Goa, India, for their support. Authors also thank Mr Sreepada, Senior scientist, for supporting with the aquaculture facility. The research work was supported by PSC0206, CSIR institutional fund. This is NIO contribution number XXXX.

\section{References}

1. Boyd CE, Tucker CS (2012) Pond aquaculture water quality management. Springer Science \& Business Media.

2. Ferreira N, Bonetti C, Seiffert W (2011) Hydrological and water quality indices as management tools in marine shrimp culture. Aquaculture 318(3-4): 425-433.

3. Mohapatra S, Chakraborty T, Kumar V, DeBoeck G, Mohanta K (2013a) Aquaculture and stress management: a review of probiotic intervention. J Anim Physiol Anim Nutr 97(3): 405-430.

4. Blancheton J, Attramadal K, Michaud L, d'Orbcastel ER, Vadstein $O$ (2013) Insight into bacterial population in aquaculture systems and its implication. Aquacult Eng 53: 30-39.

5. Martins C, Eding EH, Verdegem MC, Heinsbroek LT, Schneider O, et al. (2010) New developments in recirculating aquaculture systems in Europe: A perspective on environmental sustainability. Aquacult Eng 43(3): 83-93.

6. Sakai K, Nakamura K, Wakayama M, Moriguchi M (1997) Change in nitrite conversion direction from oxidation to reduction in heterotrophic bacteria depending on the aeration conditions. J Ferment Bioengineer 84(1): 47-52.

7. Hargreaves JA (1998) Nitrogen biogeochemistry of aquaculture ponds. Aquaculture 166(3-4): 181-212.

8. Wu Z, An Y, Wang Z, Yang S, Chen H, et al. (2008) Study on zeolite enhanced contact-adsorption regenerationstabilization process for nitrogen removal. J Hazard Mater 156(1-3): 317-326.

9. Kaushik S (1995) Nutrient requirements, supply and utilization in the context of carp culture. Aquaculture
129(1-4): 225-241.

10. Ghosh S, Pillai N, Dhokia H (2009) Fishery and population dynamics of Trichiurus lepturus (Linnaeus) off Veraval, north-west coast of India. Indian J Fish 56(4): 241-247.

11. Bachère $E$ (2003) Anti-infectious immune effectors in marine invertebrates: potential tools for disease control in larviculture. Aquaculture 227(1-4): 427-438.

12. Porubcan R (1991) Reduction of ammonia nitrogen and nitrite in tanks of Penaeus monodon using floating biofilters containing processed diatomaceous earth media pre-inoculated with nitrifying bacteria. In Proceedings of the Program and Abastracts of the 22nd Annual Conference and Exposition 3: 16-20.

13. Cutting SM (2011) Bacillus probiotics. Food Microbiol 28(2): 214-220.

14. Lalloo R, Ramchuran S, Ramduth D, Gorgens J, Gardiner $N$ (2007) Isolation and selection of Bacillus spp. as potential biological agents for enhancement of water quality in culture of ornamental fish. J Appl Microbiol 103(5): 1471-1479.

15. Pandiyan P, Balaraman D, Thirunavukkarasu R, George EGJ, Subaramaniyan K, et al. (2013) Probiotics in aquaculture. Drug Invent Today 5(1): 55-59.

16. Sadhukhan PC, Ghosh S, Chaudhuri J, Ghosh D, Mandal A (1997) Mercury and organomercurial resistance in bacteria isolated from freshwater fish of wetland fisheries around Calcutta. Environ Pollut 97(1-2): 71-78.

17. Wang YB, Li JR, Lin J (2008) Probiotics in aquaculture: challenges and outlook. Aquaculture 281(1-4): 1-4.

18. Rajasabapathy R, Mohandass C, Colaco A, Dastager SG, Santos RS, et al. (2014) Culturable bacterial phylogeny from a shallow water hydrothermal vent of Espalamaca (Faial, Azores) reveals a variety of novel taxa. Curr Sci 106(1): 58-69.

19. Lane D (1991) 16S/23S rRNA sequencing. Nuc Tech Bac Syst.

20. Kumar R, Mukherjee SC, Prasad KP, Pal AK (2006) Evaluation of Bacillus subtilis as a probiotic to Indian major carp Labeo rohita (Ham.). Aquacult Res 37(12): 1215-1221.

21. Moriarty D (1998) Control of luminous Vibrio species in penaeid aquaculture ponds. Aquaculture 164(1-4): 351358.

22. Duc LH, Hong HA, Barbosa TM, Henriques AO, Cutting SM 
(2004) Characterization of Bacillus probiotics available for human use. Appl Environ Microbiol 70(4): 21612171.

23. Rao V (2002) Bioremediation technology to maintain healthy ecology in aquaculture ponds. Fish Chimes 22(3): 39-42.

24. Wang YB, Xu ZR, Xia MS (2005) The effectiveness of commercial probiotics in northern white shrimp Penaeus vannamei ponds. Fish Sci 71: 1036-1041.

25. Taoka Y, Maeda H, JO JY, JEON MJ, Bai SC, et al. (2006) Growth, stress tolerance and non-specific immune response of Japanese flounder Paralichthys olivaceus to probiotics in a closed recirculating system. Fish Sci 72(1): 310-321.

26. Verstraete W, Focht D (1977) Biochemical ecology of nitrification and denitrification. Adv Microb Ecol Springer, pp: 135-214.

27. Lakshmanan R, Soundarapandian P (2008) Effect of commercial probiotics on large scale culture of black tiger shrimp Penaeus monodon (Fabricius). Res J Microbiol 3(3): 198-203.

28. El-Haroun E, Goda AS, Chowdhury K (2006) Effect of dietary probiotic Biogen $₫$ supplementation as a growth promoter on growth performance and feed utilization of Niletilapia Oreochromis niloticus (L.). Aquacult Res 37(14): 1473-1480.

29. Zhou XX, Wang YB, Li WF (2009) Effect of probiotic on larvae shrimp (Penaeusvannamei) based on water quality, survival rate and digestive enzyme activities. Aquaculture 287(3-4): 349-353.

30. Xie F, Zhu T, Zhang F, Zhou K, Zhao Y, et al. (2013) Using Bacillus amyloliquefaciens for remediation of aquaculture water. Springer Plus 2: 119.

31. Chen S, Hu Y (2011) Use of Bacillus subtilis in purification of slightly-polluted water. Acta Sci Circumst 31: 15941601.

32. Meng R, He L, Xi B, Hu X, Li Y (2009) Experimental study on purifying aquaculture wastewater between Bacillus and nitrifying bacteria. Environ Sci Technol (China) 32(11): 28-31.

33. Rui M, Lian-sheng HE (2011) Study on Purifying the Deteriorated Aquaculture Water with Bacteria-alga System. Adv Biomed Eng 1-2: 70-73.

34. Hong HA, Duc LH, Cutting SM (2005) The use of bacterial spore formers as probiotics. FEMS Microbiol Rev 29(4): 813-835. 